\title{
鉄道盛土の降雨崩壊に及ぼす 法面上部被覆の効果
}

\author{
岡田勝也 ${ }^{1} \cdot$ 杉山友康 $^{2} \cdot$ 布川修 ${ }^{2} \cdot$ 太田直之 ${ }^{2} \cdot$ 土屋博幸 ${ }^{3} \cdot$ 岩崎昭治 $^{3}$ \\ 1フェロー 国士舘大学 工学部都市システム工学科(テ154-8515 東京都世田谷区世田谷 4-28-1) \\ E-mail: okadak@kokushikan.ac.jp \\ 2 正会員 (財)鉄道総合技術研究所 防災技術研究部（干185-8540 東京都国分寺市光町 2-8-38） \\ 3 前・国士舘大学大学院工学研究科（干154-8515 東京都世田谷区世田谷 4-28-1）
}

\begin{abstract}
鉄道盛土では，降雨時における浸食を防ぎ，法面崩壊を防止するために法面被覆工を施工することが多 い. この法面被覆工は，侵食防止という機能以外にも，盛土本体の豪雨時の地下水上昇抑制効果もある. ここでは，砂質土からなる複線鉄道盛土を対象として，法面被覆工が法肩から法中腹にかけて，すなわち， 法面上部に被覆されたときの盛土崩壊に及ぼす地下水位抑制効果と斜面安全率について検討した. 盛土高 さ, 法面被覆工の施工長さなどをパラメーターに数值解析を行い, 豪雨時の崩壊に及ぼす被覆工の効果を 定量的に論じた。 その結果, 法面上部被覆は降雨時の盛土崩壊防止に寄与寸ることが明らかになった.さ らに，限界雨量による危険度評価手法へのこの結果の適用方法について具体的に示した。
\end{abstract}

Key Words : railway embankment, slope coverage, rainfall, unsaturated seepage flow analysis, slope stability analysis

\section{1. まえがき}

鉄道や道路などの線状構造物である盛土や切土は長雨 や集中豪雨により崩壊することがあるが，このような崩 壞は鉄道の安定輸送を阻害寸る原因のひとつになってい る ${ }^{1)}$.このため鉄道では連続雨量と時間雨量の組合せに 基づく列車の運転規制基準を定めている.

しかし，運転規制值はもともと経験的な手法に基づい て決定されていた．これに対して，筆者らは過去の降雨 による盛土・切土の災害データをもとに，連続雨量と時 間雨量のべき乗を外的基準とする多変量解析を行い，限 界雨量に基づく危険度評価手法を提案した 2),33,4),5).

この評価手法は，当初は，法面や施工基面に被覆や防 護工のない盛土や切土に対寸るものであったが，後に簡 易格子枠工や張ブロック工など，法面表面に簡易防護工 を施工した効果を含めた限界雨量による評価手法に改良 した ${ }^{6}{ }^{\circ}$ ）。この評価手法を適用寸れば，簡易な法面防護 工の一つである張ブロック工などで法面被覆された盛土 の限界雨量を求めることはできるが, 法面の被覆長さな どの幾何学的パラメーターや降雨強度などの気象学的パ ラメーターはこの評洒法には含まれていない.

そこで，筆者らはこれらのパラメーターの影響をより 明確にし, 盛土法面工の降雨崩壊に及ぼす影響について 実験的，解析的な検討を行い，法先が被覆される場合の
限界雨量による危険度評価法の適用方法を提案した ${ }^{8)}$. しかし，鉄道盛土の実態では，法肩から法先にかけて被 覆される場合もあり，これに対する被覆工の影響につい ては十分解明されていない.

当ノートでは，法面工が法肩から被覆される場合（以 下，法面上部被覆と言う）を仮定し，法面工の被覆長さ， 盛土高さと降雨強度を変化させた数值解析を行った. さ らに，この解析結果を既往の限界雨量による盛土の危険 度評価手法に適用する方法を提案した。

\section{2. 法面上部被覆盛土の解析法と入力条件}

\section{(1) 法面上部被覆を有する盛土の降雨浸透 · 安定解析 法の概要}

鉄道盛土の法面被覆が法先から法中腹にかけて施工さ れた，いわゆる下部被覆が降雨崩壊に及ぼす影響につい ては, 岡田らによる実験的, 解析的研究 ${ }^{8)}$ がある.

そこでは，まず $1 / 5$ 模型盛土の散水実験を行って，盛 土法面工の表面被覆効果について定性的な評価を行い, 降雨浸透に及ぼす法面被覆の有効性を論じた。さらに, 降雨によって円弧すべり崩壞を起こした実際の鉄道盛土 に着目し, 実降雨による地下水位変動測定データを解析 して, 定常地下水位・豪雨時地下水位と円弧す心゙り安全 


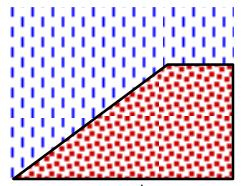

caseA

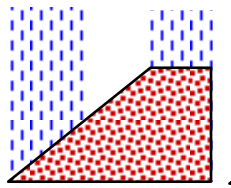

caseB

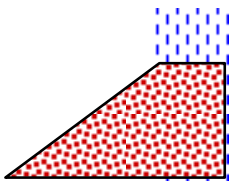

caseC

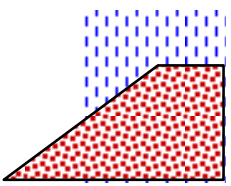

caseD

図-1＼cjkstart被覆パターン

率の追跡シミュレーションを行った．得られた結果は実 測值と十分一致することを確認した.

これを受けて，実際の鉄道盛土を対象として，図-1 の caseD に示すような下部被覆に対して，被覆長さと降 雨条件をパラメーターとした解析によって，法面被覆率 と崩壊雨量の関係を提案した。 なお, 図-1において, caseA は法面被覆のない状態, caseB は法面上部被覆, caseC は法面全面被覆を示寸.

当ノートの解析では，鉄道盛土における豪雨時の降雨 浸透と斜面崩壊の解析モデルと解析手法の妥当性が実験 的・解析的に確認されている下部被覆に対寸る上述の方 法帛を用いる。

\section{（2）法面上部被覆盛土解析のための入力条件}

\section{a）標準的な盛土の構造}

法面の被覆効果を解析するための盛土構造としては, 鉄道盛土の基本的な土工定規も考慮して，複線鉄道の施 工基面幅 $10 \mathrm{~m}$, 盛土高さ $8 \mathrm{~m}$, 法勾配 1:1.5 を基本とし た. 過去に降雨によって崩壞した 67 例の鉄道盛土の平

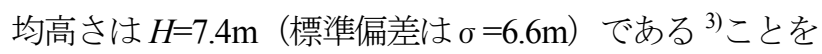
考慮して， $H=8.0 \mathrm{~m}$ を基本としたが，これに加えて， $H=4 \mathrm{~m}$ と $12 \mathrm{~m}$ についても検討する.

\section{b) 土質特性}

上述の降雨によって崩壊した 67 例の鉄道盛土のうち, $70 \%$ は砂質土であったので，本解析では砂質盛土を対象 とした.

砂質土の力学特性としては，ここでは，粘着力は無視 し, 内部摩擦角 $35^{\circ}$ とした. また, 法面に張ブロック が施工された砂質盛土 19 例についての湿潤重量と飽和 重量の頻度分布の平均值をもとに, 湿潤密度 $\rho_{\mathrm{t}}=$ $1.75 \mathrm{~g} / \mathrm{cm}^{3}$ と飽和密度 $\rho_{\mathrm{sat}}=1.96 \mathrm{~g} / \mathrm{cm}^{3}$ を求めた。

上部被覆解析に用いる保水・透水特性曲線は下部被 覆解析 ${ }^{8)}$ と同じものとした. これは，上述の張ブロッ クされた砂質盛土 19 例の保水性試験結果の平均値をも とに, Brooks-Corey 法により推定したものである. $\theta$ $\Psi$ (体積含水率一圧力水頭) $と \theta-k_{\mathrm{r}}$ (体積含水率一比 透水係数）の関係を付図-1 に示した。 これらの関係は 土質材料の違いによって異なるが，鉄道盛土の平均的な 值として代表させた，なお，飽和透水係数 $k_{\mathrm{s}}$ は，過去 に降雨によって崩壊した砂質盛土 36 例の粒度分析をも とにCreager 式によって求めた值の平均值であり， $k_{\mathrm{s}}=$

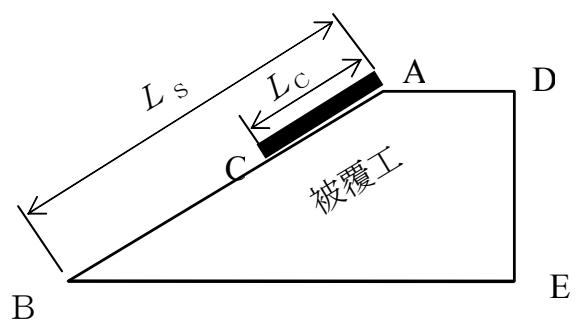

図-2＼cjkstart法面上部被覆の概念図

$1.99 \times 10^{-3} \mathrm{~cm} / \mathrm{s}$ である．また，上述の湿潤密度と飽和密 度に対応した体積含水率 $\theta$ について, 保水 - 透水特性曲 線を求める試験から得られた測定值の平均值は, それぞ れ， 0.27 と 0.32 であった. これは，降雨時の斜面安定 性を議論する上で必要となる非常に湿潤した変化を捉え るという面では妥当なものと考えられる.

\section{c) 降雨条件}

外力として与える降雨は，鉄道盛土の崩壊時の実績が， 平均が $30 \mathrm{~mm} / \mathrm{h}$, その標準偏差が $17.5 \mathrm{~mm} / \mathrm{h}$ である ${ }^{2)} こ$ とを考慮して, 時間雨量 $30 \mathrm{~mm} / \mathrm{h}$ を基準にしたが, $15 \mathrm{~mm} / \mathrm{h}$ と $45 \mathrm{~mm} / \mathrm{h}$ についても検討することにした. そ して, これらの降雨を連続して与えた.

なお，この時間雨量を与える前に，盛土堤体部の定常 地下水位を求めておく必要がある. 盛土内の定常地下水 位の計算でも，下部被覆 ${ }^{8)}$ と同様の手法を用いること にし, 日降雨量 $13.6 \mathrm{~mm} /$ day とし, 連続降雨日数 $n$ (days) と連続無降雨日数 $2 n$ (days)を合わせた $3 n$ (days)を 1 サイ クルとして繰り返し連続する降雨パターンにおいて, 多 雨期の定常地下水位を $n=1$ で与えた ${ }^{8)}$.

\section{d）被覆条件}

盛土法面に設ける被覆長さとしては，図-1 に示した 被覆が全くない caseA を基準にして, 法肩から順次被覆 長さを増加させ, 法面 1/2 被覆した caseB を経て, 法面 全面被覆の caseC に到るものとした. この法肩からの法 面被覆を上部被覆とした被覆形態の概念図を図-2 に示 した.

このとき, 降雨は, 図-2 に示すように, 被覆工によ って遮水されるものとし, 被覆されていない法面と施工 基面である路盤からだけ浸透するものとした．また，底 面・背面の境界条件としては浸入・浸出が無いものとし た. なお上部被覆された部分の降雨は法面排水工などに より処理されて, 法面下部には達しないものと仮定した. 


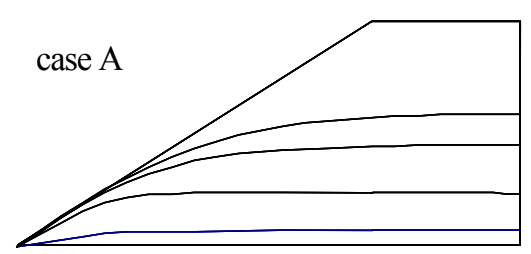

$3000 \mathrm{~min}$

$1800 \mathrm{~min}$

$600 \mathrm{~min}$

定常

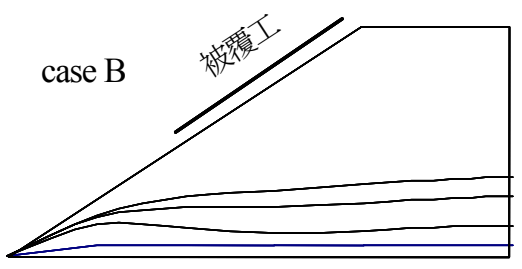

$3000 \mathrm{~min}$

$1800 \mathrm{~min}$

$600 \mathrm{~min}$

定常

図-3 盛土内地下水位の経時変化

法面被覆による被覆形態を被覆率 $N_{\mathrm{L}}$ で表すことに し, 被覆率は, 被覆工の被覆長さ $L_{\mathrm{C}}$ を法面長さ $L_{\mathrm{S}}$ で 除した $N_{\mathrm{L}}=L_{\mathrm{C}} / L_{\mathrm{S}}(=0 \sim 1)$ で与えることにした. 上部 被覆の場合には， $L_{\mathrm{S}}$ は図-2 の $\mathrm{AB}$ の法面長さ， $L_{\mathrm{C}}$ は $\mathrm{AC}$ の被覆工の被覆長さに相当する.

\section{3. 法面上部被覆の被覆効果に関する解析}

\section{（1）法面上部被覆による盛土の地下水位の断面形状}

法面上部被覆工を施工した場合の盛土断面の地下水 位分布の一例を示寸と図-3 のようになる．図の上図は 被覆の無い caseA（被覆率 $N_{\mathrm{L}}=0$ ）の場合であり, 下図 は法面を上部 $1 / 2$ 被覆した caseB（被覆率 $N_{\mathrm{L}}=0.5$ ）の 場合である。なお，盛土高さは $8 \mathrm{~m}$ で，時間雨量は $r=30 \mathrm{~mm} / \mathrm{h}$ である.

図-3 において，上図の caseA（被覆率 $N_{\mathrm{L}}=0$ ）と下 図の caseB（被覆率 $N_{\mathrm{L}}=0.5 ）$ における初期水位を比較 すると, 後者の方が幾らかは地下水位が低いものの, ほぼ同じである.

しかし，降雨が進行した両図を比較してみると，法 面被覆工の違いが地下水位形状に及ぼす影響が明らか になる。すなわち, 法面が被覆されていない caseA （被覆率 $N_{\mathrm{L}}=0$ ）の場合には，地下水位は法先から盛 土の中央に行くにつれて, 次第に上昇する傾向を示 す.

それに比べて, 被覆のある caseB（被覆率 $N_{\mathrm{L}}=0.5 ）$ 場合には，被覆工直下では降雨の浸透が遮 断されるので, 地下水位形状は平坦になる。特に, 降雨初期の場合，例えば，10 時間経過したときの被 覆面直下の地下水位形状は, 法先と施工基面直下よ りは低くなり凹形状を示し，法面被覆の影響が大き いことが判る。しかし，時間の経過につれて凹形状

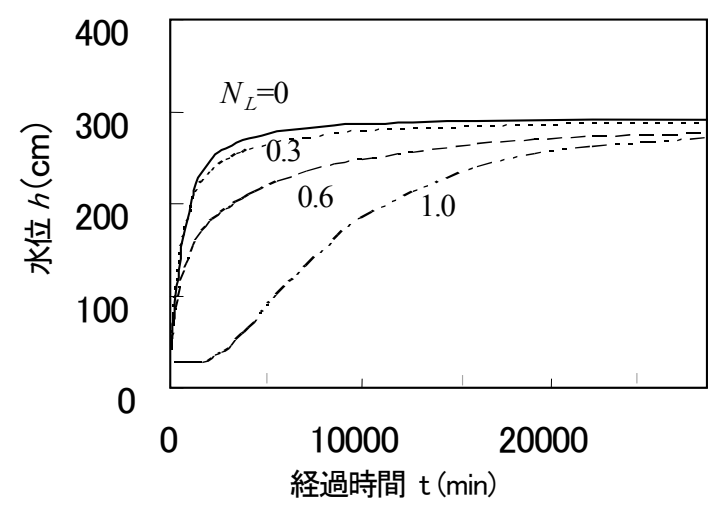

図-4 法先から $1 / 4 L_{\mathrm{S}}$ 点の地下水位 $h$ と経過時間 $t$ の関係

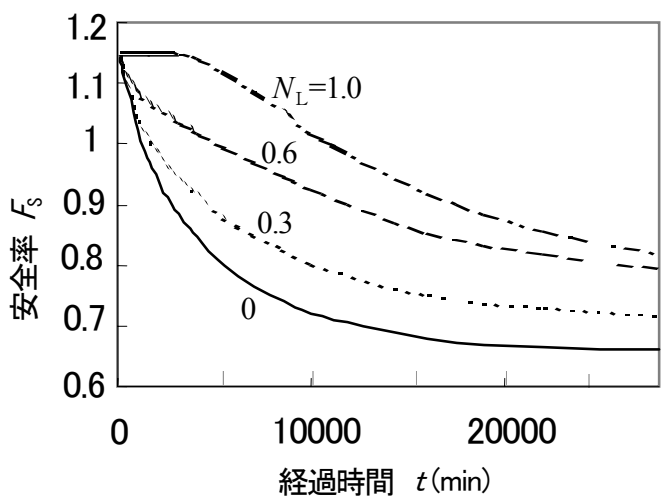

図-5 安全率 $F_{\mathrm{S}}$ と経過時間 $t$ の関係

は小さくなるものの，法面被覆による降雨遮断の影 響で, caseA（被覆率 $N_{\mathrm{L}}=0$ ）の地下水位ほじは高くな らないことが判る.

\section{（2）法面上部被覆による地下水位上昇の経時変化}

ここでは，被覆率 $N_{\mathrm{L}}$ と地下水位 $h$ の関係について 考察する. 被覆率 $N_{\mathrm{L}}$ をパラメーターに, 法先から法 面長さ $L$ の $1 / 4$ の位置（法先から $1 / 4 L_{\mathrm{S}}$ 点）における地 下水位 $h$ の時間的変化を描いてみると, 図-4 のように なる.

被覆の無い $N_{\mathrm{L}}=0$ の場合, 地下水位は降雨の継続に つれて急速に大きくなり, 経過時間 $t$ が $5000 \mathrm{~min}$ を過 ぎるとほほ一定の水位になる。 しかし, 被覆率 $N_{\mathrm{L}}$ が 大きくなるにつれて，水位上昇の立ち上がり勾配は小 さくなっていく. 全面被覆の $N_{\mathrm{L}}=1$ の場合には，初め の $1000 \mathrm{~min}$ は定常地下水位のままで, そ水以降地下水 位は緩やかに上昇していくのが判る.

このように法面を被覆することによって，特に降雨 開始の時期には，地下水位上昇の速度を抑えることが できる. 


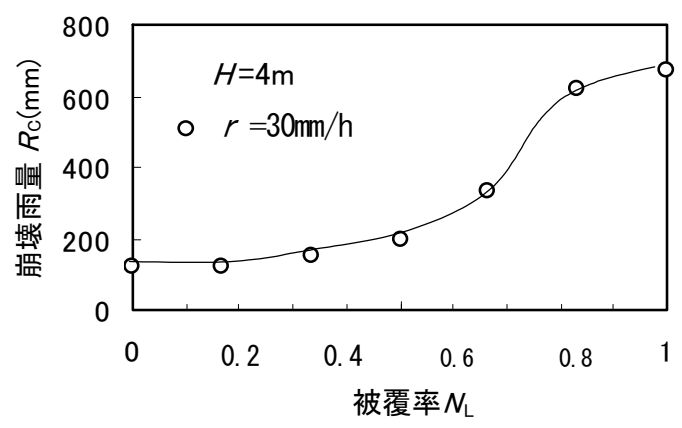

図-6 被覆率 $N_{\mathrm{L}}$ と崩壊雨量 $R_{\mathrm{C}}$ との関係 $(H=4 \mathrm{~m})$

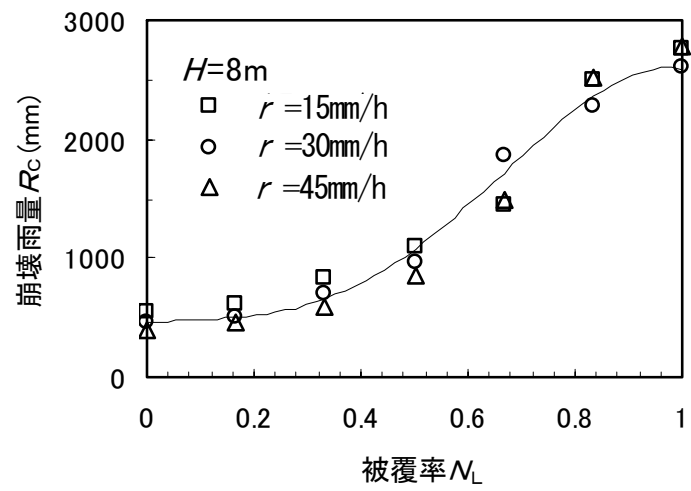

図-7 被覆率 $N_{\mathrm{L}}$ と崩壊雨量 $R_{\mathrm{C}}$ との関係 $(H=8 \mathrm{~m})$

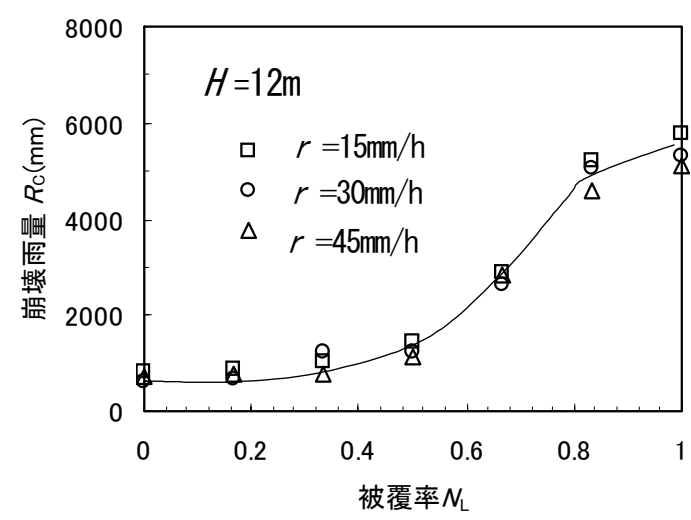

図-8 被覆率 $N_{\mathrm{L}}$ と崩壊雨量 $R_{\mathrm{C}}$ との関係 $(H=12 \mathrm{~m})$

（3）法面上部被覆による円弧すべり安全率の経時変化

盛土の地下水位上昇に伴って, 円弧すべり安全率 $F_{\mathrm{S}}$ は低下する． $F_{\mathrm{S}}$ の計算には修正フェレニウス法を用い たが，その概要は付録に示した。

図-5 は安全率 $F_{\mathrm{S}}$ と経過時間 $t$ の関係を, 被覆率 $N_{\mathrm{L}}$ をパラメーターにして，描いたものである。

被覆のない $N_{\mathrm{L}}=0$ の場合には, 地下水位の上昇が早 いので，安全率 $F_{\mathrm{S}}$ の低下は急激である． $N_{\mathrm{L}}$ が大きく なるにつれて, 安全率 $F_{\mathrm{S}}$ の低下傾向は鈍化する. 全 面被覆の $N_{\mathrm{L}}=1.0$ の場合には，経過時間 $t$ が小さいと きには $F_{\mathrm{S}}$ の低下はなく, その後緩やかに $F_{\mathrm{S}}$ が低下し ていく傾向を示す.

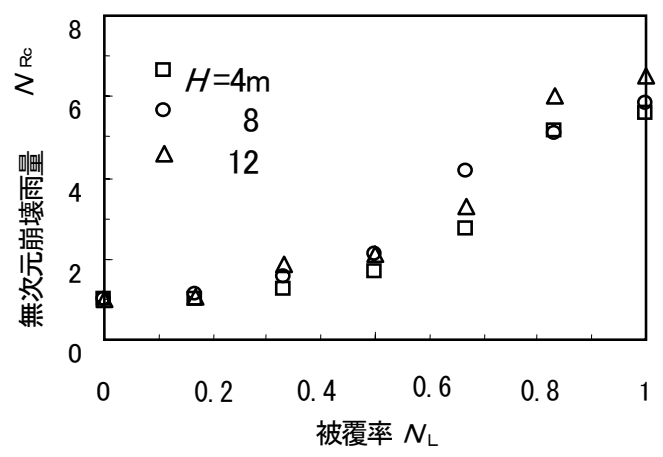

図-9 被覆率 $N_{\mathrm{L}}$ と無次元崩壊雨量 $N_{\mathrm{RC}}$ との関係

\section{（4）法面上部被覆が崩壊雨量に及ぼす影響}

降雨の継続によって安全率 $F_{\mathrm{S}}$ が低下し， $F_{\mathrm{S}}=1$ とな ったときの降雨開始からの累積雨量を崩壊雨量 $R_{\mathrm{C}}$ と 定義する。実際には，この崩壊雨量の水位形成に至 るまでに，表面浸食，パイピングなどで法面が崩壊 することもあるが，ここではこのような現象につい ては考えないことにした。

崩壊雨量 $R_{\mathrm{C}}$ と被覆率 $N_{\mathrm{L}}$ との関係を, 盛土高さ $H$ 別 に描くと，図-6，7 と 8 のようになる. $H=4 \mathrm{~m}$ に対す る図-6 は時間雨量が $r=30 \mathrm{~mm} / \mathrm{h}$ の例であるが, $H=$ $8 \mathrm{~m}$ の図-7 と $H=12 \mathrm{~m}$ の図-8 はいずれも $r=15,30$ と $45 \mathrm{~mm} / \mathrm{h}$ について描いたものである.これらの図から, 被覆率 $N_{\mathrm{L}}$ が大きくなるにつれて崩壊雨量 $R_{\mathrm{C}}$ が高くな るのは，被覆による効果が大きくなることを示してい る. なお，それぞれの崩壊雨量 $R_{\mathrm{C}}$ は時間雨量 $r$ の影響 をほとんど受けないことも判る.

そこで，これらの図を時間雨量 $r=30 \mathrm{~mm} / \mathrm{h}$ におけ る被覆のない $\left(N_{\mathrm{L}}=0\right)$ 場合の崩壊雨量を基準にして, それぞれの盛土高さ $H$ について，無次元化を行ったの が，図-9 である.これによれば，被覆率 $N_{\mathrm{L}}$ と無次元 崩壊雨量 $N_{\mathrm{RC}}$ の関係は，盛土高さ $H$ にはあまり関係 ないことが判る。この理由は, 盛土高さ $H$ を変化させ ても，法面被覆による雨水浸透を遮断する幾何学的な 割合は同じであるからだと考えられる。

従って，この図を用いることにより，被覆の無い盛 土（ $N_{\mathrm{L}}=0 ）$ の任意の時間雨量 $r$ に対する崩壊雨量 $R_{\mathrm{C}}$ が判れば，任意の被覆長さに対する崩壊雨量を推定す ることが可能である.

\section{4. 法面上部被覆の被覆率の盛土危険度評価法へ の適用}

\section{（1）法面上部被覆に対する被覆効果率}

鉄道盛土の危険度評価手法によれば，限界雨量は，連 


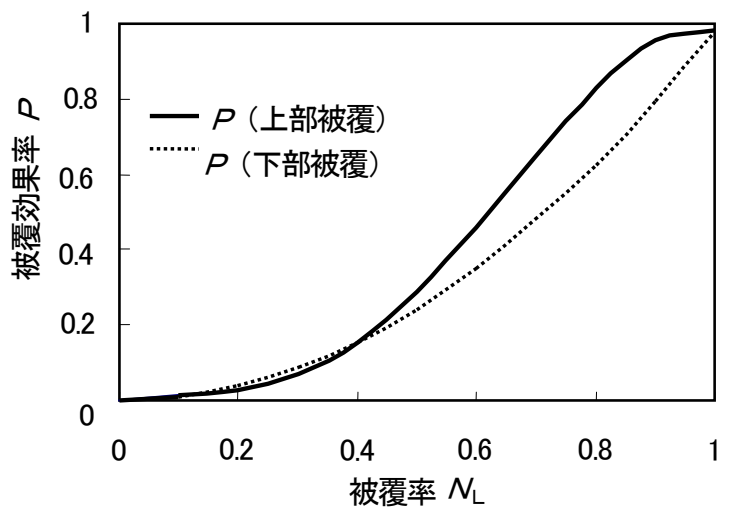

図-10 被覆率 $N_{\mathrm{L}}$ と被覆効果率 $P$ の関係

続雨量 $R$, 時間雨量 $r$ に対して, $R^{0.3} r^{0.3}$ で表される. この限界雨量は，法面が全く被覆されていない状態 ${ }^{2)}$, あるいは張ブロックなどによって法面全体が被覆され ている場合 6に限られる.

しかし，現実には法面の下部あるいは上部だけが張ブ ロックなどで被覆されている箇所もある.ここでは，3 の解析結果に基づいて，法面上部に部分的な被覆工が施 工されたときの危険度評価手法の適用について検討する。

そこで，任意の被覆率 $N_{\mathrm{L}}$ に対する崩壊雨量の定量化 を行うために，下部被覆 ${ }^{8)}$ と同様に，被覆効果率 $P$ を 次のように定義した.

$$
P=\frac{R_{\mathrm{NL}=\mathrm{i}}-R_{\mathrm{NL}=0}}{R_{\mathrm{NL}=1}-R_{\mathrm{NL}=0}}
$$

すなわち，3.の解析で得られた被覆率 $N_{\mathrm{L}}=1$ におけ る崩壊雨量 $R_{\mathrm{NL}=1}$ と被覆率 $N_{\mathrm{L}}=0$ における崩壊雨量 $R_{\mathrm{NL}=0}$ との差を基準として，任意の被覆率の崩壊雨量 $R_{\mathrm{NL}=\mathrm{i}}$ と $R_{\mathrm{NL}=0}$ の差との比として定義した.

式(1)から求まる上部被覆に対する被覆効果率 $P$ (上 部被覆）を被覆率 $N_{\mathrm{L}}$ との関係で示すと図-10（上部被 覆）ようになる. なお, ここでは, 被覆率 $N_{\mathrm{L}}$ と無次 元崩壊雨量 $N_{\mathrm{R}}$ の関係は, 図-6, 7 と 8 で示したよう に時間雨量 $r$ にはほとんど関係ないので，時間雨量 $r=30 \mathrm{~mm} / \mathrm{h}$ の場合について示した. しかし，図-9 に示 したように盛土高さ $H$ に対して無時限崩壊雨量 $N_{\mathrm{RC}}$ は多少のばらつきがあるので, 図-10 の被覆効果率 $P$ (上部被覆）も多少のばらつきを有することになるが， 図-10 のようなほぼ一つの非線形な関係で代表するこ とができ, 次式で表される. 寸なわち, 被覆効果率 $P$ (上部被覆) は,

$$
P=-4.76 N_{\mathrm{L}}^{4}-7.31 N_{\mathrm{L}}^{3}-1.823 N_{\mathrm{L}}^{2}-0.25 N_{\mathrm{L}}
$$

で与えられる.

式(2)によって，任意の被覆率 $N_{\mathrm{L}}$ で盛土法面を上部 被覆したときの被覆効果率 $P$ (上部被覆) が決定でき るので，そのときの限界雨量 $R^{0.3} r^{0.3}\left(N_{\mathrm{L}}\right)$ は岡田ら ${ }^{2)}$ の
の手法による被覆率 $N_{\mathrm{L}}=0$ に対する限界雨量 $R^{0.3} r^{0.3}$ $\left(N_{\mathrm{L}}=0\right)$ と杉山ら $\left.{ }^{6}\right)$ の手法による被覆率 $N_{\mathrm{L}}=1$ に対 する限界雨量 $R^{0.3} r^{0.3} \quad\left(N_{\mathrm{L}}=1.0\right)$ を求めさえしておけば, 容易に決定できることになる.

\section{（2）被覆効果率に対する上部被覆と下部被覆の比較}

前述の (1) では，法肩から被覆した場合の被覆効果 率 $P$ (上部被覆) を誘導した。ここでは，法先から被 覆された場合の被覆効果率 $P$ (下部被覆) との比較に ついて述べる.

下部被覆に対する被覆効果率 $P$ (下部被覆) は,

$$
P=0.993 N_{\mathrm{L}}^{2}-0.012
$$

で与えられている ${ }^{8)}$.

式(3)の関係を図-10 に点線（下部被覆）として追加 した。 下部被覆の場合には下に凸の放物線で近似でき たのに，上部被覆の場合には $\mathrm{S}$ 字曲線を示す。被覆率 が $N_{\mathrm{L}}<0.4$ の場合には，両者の被覆効果率 $P$ はほぼ同 じである。しかし，法肩近傍が被覆されることによっ て地下水位上昇が抑えられる効果が出てくるのは $N_{\mathrm{L}}>$ 0.4 の領域で, この場合には被覆効果率 $P$ (上部被覆) の方が被覆効果率 $P$ (下部被覆）よりも大きくなるこ とが判る.

\section{5. まとめ}

盛土法面の上部被覆が降雨崩壊に及ぼす影響につい て述べた。その結果，豪雨時の地下水位上昇に起因す る盛土崩壊防止には, 法面上部の被覆による遮水工も 有効であることが明らかになった，得られた結果をま とめると次のようになる.

(1) 砂質土からなる鉄道盛土を対象として, 法面被覆 効果について解析した結果, 上部法面被覆は崩壊に 至るまでの時間を長くし, その結果として崩壊雨量 を大きくする.

(2) 崩壊に至るまでの時間と崩壊雨量に及ぼす影響は, 被覆率 $N_{\mathrm{L}}$ が小さい場合には，比較的小さい。しか し，被覆率 $N_{\mathrm{L}}$ が 0.4 以上になるとその影響は急激 に大きくなり，0.8より大きくなると鈍化する.

(3) 被覆率 $N_{\mathrm{L}}$ を用いることによって, 被覆のない $\left(N_{\mathrm{L}}=0\right)$ 時の崩壊雨量 $R_{\mathrm{C}}$ から, 任意の被覆率 $N_{\mathrm{L}}$ に対する $R_{\mathrm{C}}$ を予測することができる.

(4) 無次元崩壊雨量 $N_{\mathrm{R}_{\mathrm{c}}}$ と被覆率 $N_{\mathrm{L}}$ の関係は, 盛土高 さ $H$ と時間雨量 $r$ にかかわらずほぼ一定である.

（5）上部被覆した法面工を有する盛土に限界雨量によ る危険度評価法を適用する場合, 式(2)に示す被覆 効果率 $P$ (上部被覆)を用いることができる. 


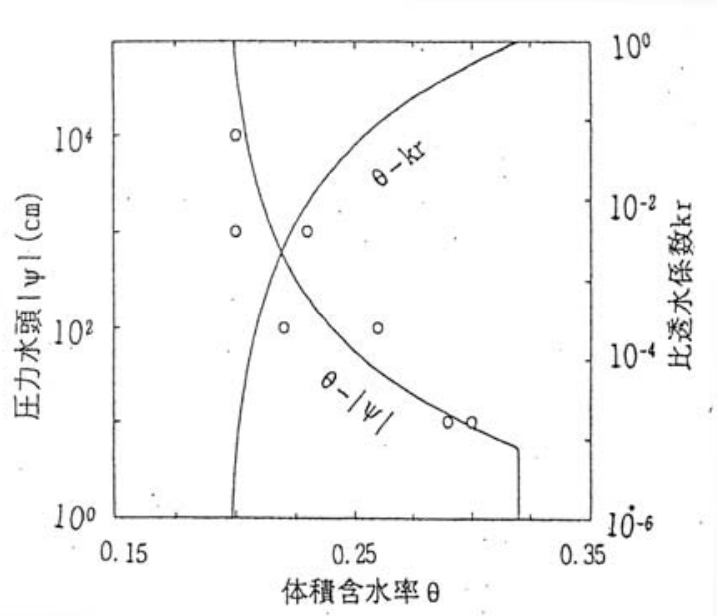

付図-1 砂質盛土の保水・透水特性（文献 8）による）

(6) 被覆効果率 $P$ (上部被覆) と被覆効果率 $P$ (下部被 覆）について比較すると, $N_{\mathrm{L}}>0.4$ の領域では上部 被覆の方が下部被覆よりも被覆効果率が大きくなる。

\section{付録}

本論文で用いた保水・透水特性曲線の $\theta-\Psi$ (体積含 水率一圧力水頭）と $\theta-k_{\mathrm{r}}$ （体積含水率一比透水係 数) ${ }^{8)}$ を付図-1 に示した.

また，極限平衡法による斜面安定解析には，次に示 す修正フェレニウス法を用いた。すなわち,

$$
F_{\mathrm{S}}=\frac{\sum\left(c L+W^{\prime} \cos \alpha \tan \phi\right)}{\sum W \sin \alpha}
$$

ここに， $F_{\mathrm{S}}, W, W, L, \alpha, c$ と $\phi$ は, それぞれ, 円弧す ベり安全率，スライスの全重量（土，水，上載荷重の 和）, スライスの有効重量（地下水位以下では水中重 量），スライス底面の長さ，スライス底面が水平面とな す角度と，土の粘着力と内部摩擦角である.

\section{参考文献}

1)日本国有鉄道土木課 : 土木建造物取替の考え方, 日本鉄道 施設協会, pp.1-823, 1974.

2)岡田勝也, 杉山友康, 村石尚, 野口達雄 : 統計的手法によ る鉄道盛土の降雨崩壊危険度評価法, 土木学会論文集, No.448/III-19, pp.25-34, 1992.

3) Okada, K., Sugiyama, T., Muraishi, H., Noguchi, T. and Samizo, M.: Statistical Risk Estimationg Method for Rainfall on Surface Collapse of Cut Slope, Soils and Foundations, Vol.34, No.4, pp.48-58, 1994.

4) Sugiyama, T., Okada, K., Muraishi, H., Noguchi,T. and Samizo, M.: Statistical Rainfall Risk Estimationg Method for Deep Collapse of Cut Slope, Soils and Foundations, Vol.35, No.4, pp.37-48, 1995.

5)杉山友康 : 降雨時の斜面崩壊防止のための危険度評価法に 関する研究，鉄道総研報告，特別号 19 号，pp.1-239，1997.

6)杉山友康, 岡田勝也, 秋山保行, 村石尚, 奈良利孝 : 鉄道 盛土の崩壊限界雨量に及ぼす防護工の効果，土木学会論文 集, No.664/III-46, pp.161-171, 2000.

7)岡田勝也, 杉山友康 : 鉄道斜面（盛土，切取）の限界雨量に よる崩壊予測法とその適用, 土と基礎, Vol.49, No.7, pp.22-24, 2001.

8)岡田勝也, 杉山友康, 太田直之, 布川修, 柴田英明 : 鉄道盛土 の法面被覆が降雨崩壊に及ぼす影響, 土木学会論文集, No.778/III-69, pp.111-124, 2004.

(2006. 3. 31 受付)

\section{EFFECT OF UPPER SURFACE COVERING OVER RAILWAY EMBANKMENT SLOPES ON RAIN-INDUCED SLOPE FAILURE}

\section{Katsuya OKADA, Tomoyasu SUGIYAMA, Naoyuki OTA, Osamu NUNOKAWA, Hiroyuki TUCHIYA and Shoji IWASAKI}

It is common practice to cover railway embankment slopes with protective materials to prevent raininduced slope failure. Although slope covering of this type is designed mainly for erosion control, it also has the effect of helping prevent the groundwater level rising through the embankment body in the event of heavy rain. This study investigates the groundwater level lowering effect of protective covering over the upper half of the slope of a railway embankment made of sandy material, and the factor of safety of the slope that can be achieved by such slope covering. A numerical analysis parameterizing such factors as embankment height and slope covering length is conducted, and the effect of slope covering on slope failure due to heavy rain is investigated quantitatively. The study has revealed that upper surface covering over an embankment slope helps prevent rain-induced slope failure. This paper also proposes a procedure for applying these results to a risk evaluation method based on critical rainfall. 